УДК 618.396- 092-084

DOI 10.11603/24116-4944.2021.1.12366

๑В. П. Міщенко, В. В. Міщенко, Г. Л. Лавриненко, І. Л. Головатюк-Юзефпольська, С. В. Білоусов, В. М. Котляренко

Одесъкий національний медичний університет

\title{
ПАТОГЕНЕТИЧНЕ ОБГРУНТУВАННЯ АЛГОРИТМУ ПІДГОТОВКИ ДО ВАГІТНОСТІ МАЙБУТНІХ БАТЬКІВ ЗІ ЗВИЧНИМ НЕВИНОШУВАННЯМ В АНАМНЕЗІ ЖІНОК
}

Мета дослідження - зниження частоти та тяжкості гестаційних ускладнень у жінок зі звичним невиношуванням вагітності шляхом проведення персоніфікованої передконцепційної підготовки.

Матеріали та методи. Обстежено 135 осіб репродуктивного віку. 45 жінок (група Аж), які страждали від звичного невиношування, 45 їх чоловіків (група Ач), які пройшли запропоновану передконцепційну підготовку, та 45 жінок (група Б) 3 обтяженим анамнезом звичним невиношуванням. Було розроблено та запропоновано алгоритм комплексної персоніфікованої передконцепційної підготовки. Всім пацієнтам було проведено загальновизнане обстеження відповідно до нині діючих клінічних протоколів, затверджених наказами МОЗ України.

Результати дослідження та їх обговорення. Супутня соматична патологія у жінок склала до 73,3 \%. Інфекційні процеси піхви в анамнезі мали майже 100 \% жінок, запальні процеси шийки матки (ендоцервіцит, цервіцит) - 60,0 і 62,2 \%, лейоміому матки - 28,9 і 26,7 \%, ендометріоз - 11,1 і 13,3 \%, хронічний ендометрит - 8,9 і 11,1 \%, хронічний сальпінгооосорит - 13,3 і 15,6 \%, порушення менструальної фрункції - 44,4 і 46,7 \% обстежуваних груп Аж і Б. У чоловіків патологію сперматогенезу виявлено у 31,1 \%, урогенітального тракту - у 55,6 \% обстежуваних. У жінок груп Аж і Б гомозиготний поліморфізм MTHFR був виявлений - у 32,2 \% і гетерозиготний - у 43,3\%.

Поєднаний поліморфізм генів фролатного циклу MTHFR 1298 A/C, MTHFR 677 C/T, MTR 2756 A>G, MTRR 66 A>G в обстежуваного контингенту був у межах від 66,7 до 80,0 \% спостережень. У групі жінок, які проходили запропоновану комплексну етапну передконцепційну підготовку з біологічними батьками дітей, достовірно знижена частота синдрому загрози раннього викидня у 2,1 раза, відшарування хоріона - у 3,6 раза, пізнього викидня - у 3,1 раза.

Висновки. При звичному невиношуванні потрібні обстеження і підготовка майбутніх батьків відповідно до персоніфрікованого алгоритму за 3-4 місяці до запліднення, в тому числі за результатами спадкової схильності до порушень фолатного циклу із призначенням препарату «Метафолін» у фрізіологічних дозах.

Ключові слова: передконцепційна підготовка; звичне невиношування; гени фолатного циклу.

ПАТОГЕНЕТИЧЕСКОЕ ОБОСНОВАНИЕ АЛГОРИТМА ПОДГОТОВКИ К БЕРЕМЕННОСТИ БУДУЩИХ РОДИТЕЛЕЙ С ПРИВЫЧНЫМ НЕВЫНАШИВАНИЕМ В АНАМНЕЗЕ ЖЕНЩИН

Цель исследования - снижение частоты и тяжести гестационных осложнений у женщин с привычным невынашиванием беременности путем проведения персонисицированной предконцепционной подготовки.

Материалы и методы. Обследовано 135 человек репродуктивного возраста. 45 женщин (группа Аж), страдающих привычным невынашиванием, 45 их мужчин (группа Ам), которые прошли предложенную предконцепционную подготовку, и 45 женщин (группа Б) с отягощенным анамнезом привычным невынашиванием. Был разработан и предложен алгоритм комплексной персонифицированной предконцепционной подготовки. Всем пациентам было проведено общепризнанное обследование в соответствии с ныне действующими клиническими протоколами, утвержденными приказами МОЗ Украины.

Результаты исследования и их обсуждение. Сопутствующая соматическая патология у женщин составила до 73,3 \%. Инфрекционные процессы влагалища в анамнезе имели почти $100 \%$ женщин, воспалительные процессы шейки матки (эндоцервицит, цервицит) - 60,0 и 62,2 \%, лейомиому матки - 28,9 и 26,7 \%, эндометриоз - 11,1 и 13,3 \%, хронический эндометрит - 8,9 и 11,1 \%, хронический сальпингооофорит - 13,3 и 15,6 \%, нарушение менструальной фрункции - 44,4 и 46,7 \% обследуемых групп Аж и Б. У мужчин патологию сперматогенеза обнаружено в 31,1 \%, урогенитального тракта - в 55,6 \% обследуемых. У женщин групп Аж и Б гомозиготный полиморфизм MTHFR был обнаружен в 32,2 \% и гетерозиготный - в 43,3 \%. Сочетанный полиморсизм генов фолатного цикла MTHFR 1298 A/C, MTHFR 677 C/T, MTR 2756 A>G, MTRR 66 A>G у обследуемого контингента был в пределах от 66,7 до 80,0 \% наблюдений. В группе женщин, которые проходили предложенную комплексную этапную предконцепционную подготовку с биологическими родителями детей, достоверно снижена частота синдрома угрозы раннего выкидыша в 2,1 раза, отслойки хориона - в 3,6 раза, позднего выкидыша в 3,1 раза.

Выводы. При привычном невынашивании необходимы обследование и подготовка будущих родителей согласно персонифицированного алгоритма за 3-4 месяца до оплодотворения, в том числе по результатам наследственной предрасположенности к нарушениям фолатного цикла с назначением препарата «Метафолин» в физиологических дозах.

Ключевые слова: предконцепционная подготовка; привычное невынашивание; гены фролатного цикла.

PATHOGENETIC JUSTIFICATION OF THE ALGORITHM OF PREPARATION FOR PREGNANCY OF FUTURE PARENTS WITH HABITUAL MISCARRIAGE IN ANAMNESIS OF WOMEN

The aim of the study - to reduce the frequency and severity of gestational complications in women with recurrent miscarriage, by carrying out personalized preconception preparation.

Materials and Methods. 135 people of reproductive age were examined. 45 women (group Aw) suffering from recurrent miscarriage, 45 of them men (group Am) who underwent the proposed preconception preparation, and 45 women (group B) with a history of recurrent miscarriage. An algorithm for complex personalized preconception preparation was developed and proposed. All patients underwent a generally recognized examination in accordance with the current clinical protocols approved by the orders of the Ministry of Health of Ukraine. 
Results and Discussion. Concomitant somatic pathology in women was up to $73.3 \%$. Almost $100 \%$ of women had a history of vaginal infections, cervical inflammatory processes (endocervicitis, cervicitis) $-60.0 \%$ and $62.2 \%$, uterine leiomyoma -28.9 and $26.7 \%$, endometriosis -11.1 and $13.3 \%$, chronic endometritis -8.9 and $11.1 \%$, chronic salpingo-oophoritis - 13.3 and $15.6 \%$, menstrual dysfunction -44.4 and $46.7 \%$ of the examined groups A and B. The pathology of spermatogenesis was found in men in $31.1 \%$, of the urogenital tract - in $55.6 \%$ of the examined. Homozygous MTHFR polymorphism was found in $32.2 \%$ and heterozygous - in $43.3 \%$ in women of groups A and B. The combined polymorphism of the folate cycle genes MTHFR 1298 A/C, MTHFR $677 \mathrm{C} /$ T, MTR $2756 \mathrm{~A}>\mathrm{G}$, MTRR $66 \mathrm{~A}>\mathrm{G}$ in the surveyed population ranged from $66.7 \%$ to $80.0 \%$ of observations. The frequency of the syndrome of the threat of early miscarriage was significantly reduced by 2.1 times, chorionic detachment by 3.6 times, and late miscarriage by 3.1 times in the group of women who underwent the proposed complex staged pre-conceptual training with the biological parents of children.

Conclusions. It is necessary to examine and prepare future parents according to a personalized algorithm 3-4 months before fertilization, including, according to the results of a hereditary predisposition to violations of the folate cycle with the prescription of Metafolin in physiological doses in case of recurrent miscarriage.

Key words: preconception preparation; habitual miscarriage; folate cycle genes.

ВСТУП. Звичне невиношування вагітності (ЗНВ) становить серйозну проблему в медицині і суспільстві $[1,2]$. Впродовж останніх десятиріч немає тенденції до зниження цієї патології в усіх країнах світу $[3,4]$. Репродуктивні втрати, в тому числі звичне невиношування вагітності, - це патологія мультифракторної природи [5-10].

Попередження патології мультифракторної природи багатоетапний процес $[11,12]$. Важливою є підготовка до вагітності майбутніх батьків обох статей (чоловік/жінка). Визначення можливих причинних чинників як в організмі жінки, так і чоловіка є одним із основних показників до складання алгоритму передконцепційної підготовки та профрілактичних заходів із позицій предиктивної медицини [4, 13-15].

Передчасне повторне переривання вагітності у різні терміни може сприяти виникненню гінекологічної (істміко-цервікальної недостатності, інфекційних процесів матки та її придатків, шийки тощо), соматичної (анемій, неврозів, судинних захворювань тощо) патології, що ускладнюватиме виношування наступної вагітності [1618]. Окрім цього, звичне невиношування вагітності, як і репродуктивні втрати в цілому, є тяжкою психологічною травмою не лише для жінки, але і їі чоловіка та членів сім'ї $[19,20]$. Перший викидень, звичне невиношування (коли відбулося 2-3 і більше викиднів) за патогенетичним механізмом $є$ наслідком патологічних процесів, що виникають у відповідь на дію складних взаємопов'язаних метаболічних порушень в організмі жінки на розвиток вагітності [21, 22]. У виникненні патології ембріона й хоріона, плода і плаценти мають значення всі можливі провокуючі фрактори: генетичний компонент, термін гестації, тригерні чинники, деструкція тканин тощо [22-24]. Важливою $€$ генетична спадковість майбутніх батьків. Велике значення надається фрізіологічному фрункціонуванню фрерментної системи, гормонів тощо, можливим негативним наслідкам впливу зовнішнього середовища на організм матері з позицій епігенетики [22-27]. Метаболічні процеси в організмі людини взаємопов'язані і взаємозалежні між собою за механізмом дії різних речовин, продуктів їхнього розпаду та виведення зовні $[28,29]$. У разі патології мультифракторної природи ці процеси перебігають за патологічним типом $[10,28]$.

Поліетіологічність проблем звичного невиношування вагітності пояснює постійний пошук науковців щодо нових методів діагностики, профрілактики, терапії та попередження цієї патології з позицій предиктивної медицини
[11, 30-35]. Останнє ґрунтується на персоніфрікованому підході шляхом корекції метаболічних процесів в організмах майбутніх батьків.

МЕТА ДОсЛІДЖЕНнЯ - зниження частоти та тяжкості гестаційних ускладнень у жінок зі звичним невиношуванням вагітності в анамнезі шляхом проведення персоніфікованої передконцепційної підготовки майбутніх батьків.

МАТЕРІАЛИ ТА МЕТОДИ. Обстежено 135 (90 жінок і 45 чоловіків) осіб репродуктивного віку із числа мешканців міста Одеси. Основна (А) група об'єднала 45 сімейних пар: 45 жінок (група Аж), які страждали від звичного невиношування, та 45 їхніх чоловіків (група Ач).

Пацієнти обох статей основної групи пройшли запропоновану передконцепційну підготовку. Контрольна група представлена 45 жінками (група Б) з обтяженим анамнезом звичним невиношуванням. Розроблений та запропонований алгоритм передконцепційної підготовки включав: 1) збір анамнезу (соматичного, сімейного через два покоління, професійного, акушерсько-гінекологічного, андрологічного тощо); 2) визначення особливостей клінічного перебігу періоду до - і після переривання вагітності; 3) визначення обсягу обстеження чоловіка/ жінки та можливих причинних чинників, які сприяють невиношуванню вагітності; 4) розробку персоніфікованих алгоритмів підготовки до вагітності за часом, обсягом, змістом; 5) характеристику якості харчування, способу життя, наявності шкідливих звичок; 6) вивчення показань та препаратів, які пацієнтки приймали «в системі» за показаннями; 8) визначення генів фрерментів фолатного циклу методом ПлР (MTHFR (метилентетрагідрофолатредуктаза) 1298 A/C, MTHFR (метилентетрагідрофолатредуктаза) $677 \mathrm{C} / \mathrm{T}, \mathrm{MTR}$ (метіонін-синтаза) $2756 \mathrm{~A}>\mathrm{G}$, MTRR (метіонін-синтаза-редуктаза) $66 \mathrm{~A}>\mathrm{G}$ ); 9) вивчення результатів спермограм, андрофолори тощо; 11) розробку персоніфікованих алгоритмів ведення вагітних у I, II, III триместрах. Всім пацієнтам було проведено загальновизнане обстеження відповідно до нині діючих клінічних протоколів, затверджених наказами МОЗ України.

Пацієнти групи А (Аж, Ач) проходили обстеження за 4-6 місяців до передбачуваного природного запліднення. Алгоритм комплексної персоніфрікованої підготовки включав: 1) за наявності показань: санацію осередків інфекції, в тому числі за даними результатів фемофрлор/ андросрлор; корекцію процесу сперматогенезу; стабілізацію соматичної, гінекологічної патології; психологічну 
підтримку; мікронутрієнтну підтримку; вживання продуктів, що містять природні фоолати; вітамінні, мікроелементні, амінокислотні комплекси, що містять фолати 400 мкг (фолієву кислоту 200 мкг, кальцій-L-Метилфолат (Metafolin - еквівалентно 200 мкг фролієвої кислоти), докозагексанову кислоту 200 мг, вітамін Е 12 мг) в дозі 1 таблетка і 1 капсула 1 раз на день впродовж 3 місяців. Цей препарат жінки продовжували приймати в II, III триместрах і періоді лактації. У I триместрі застосовували комплекс без вказаних кислот. Пацієнти (чоловік/жінка), які приймали «в системі» за показаннями антиепілептичні (карбамазепан, вальпроат та ін.) препарати, сульфосалазин, метотрексат, та пацієнти «носії» 4-х гомозиготних алелів генів фрерментів фолатного циклу застосовували вітамінні, мікроелементні, амінокислотні комплекси, що містять фолати в більших дозах: 400 мкг метафоліну (у вигляді 451 мкг кальцію-L-Метилфолат в перерахунку на фолієву кислоту) в дозі 1 таблетка і 1 капсула 1 раз на день впродовж 3 місяців. Із 16 тижнів вагітності жінки застосовували комплекси, що містять фолати в дозі 400 мкг (фолієву кислоту 200 мкг, кальцію-L-Метилфолат (Metafolin - еквівалентно 200 мкг фолієвої кислоти)).

Отримані результати оброблено із застосуванням методик математичної статистики і використанням пакета програм MS Excel XP, Statistica 6.0. Порівняння груп хворих і отриманих числових характеристик проводили із застосуванням параметричного критерію Стьюдента. При цьому статистично значущими вважали відмінності при $\mathrm{p}<0,05$.

РЕЗУЛЬТАТИ ДОСЛІДЖЕННЯ ТА ЇХ ОБГОВОРЕН-

ня. Результати обстеження 135 пацієнтів підтвердили індивідуальні особливості гомеостазу кожного організму. Середній вік жінок склав $(23 \pm 2)$ роки, чоловіків - (27士2) роки. Усі обстежувані були мешканцями Одеської області з народження. Вивчення соматичного анамнезу та соматичної патології за результатами обстеження показало, що серцево-судинні захворювання склали 31 (68,9 \%), 32 (71,1 \%), шлунково-кишкового тракту - 32 (71,1 \%), 33 (73,3 \%), гепатобіліарної системи - 28 (62,2 \%), 29 (64,5 \%), сечовивідної системи - 23 (51,1 \%), 22 (48,9\%), хронічні закрепи - 27 (60,0 \%), 25 (55,6 \%), анемії різної етіології - 16 (35,6 \%), 17 (37,8\%), ендокринопатії - 27 (60,0 \%), 28 (62,2 \%), захворювання щитоподібної залози - 28 (62,2\%), 29 (64,4\%), ожиріння - 12 (26,7\%), 13 (28,9 \%), захворювання ЦНС - 10 (22,2 \%), 11 (24,4 \%) відповідно за групами Аж і Б. Більшість жінок приймала медикаментозні засоби впродовж останнього року. Не виявлено достовірної різниці між показниками частоти захворюваності за групами. Звертає на себе увагу наявність поліморбідності у жінок. Поєднана патологія, часті загострення екстрагенітальних захворювань, ендокринопатії, поліпрагмазія можуть бути як тригерними чинниками, так і одними із численних ланцюгів патогенетичного кола звичного невиношування вагітності [2, 3, 5].

Клінічний приклад 1. Пацієнтка 32 років. В анамнезі 5 спонтанних абортів у ранні терміни, 1 антенатальна загибель плода в 20 тижнів. Репродуктивні втрати впродовж 3-х років. Шлюб перший. Виявлено полінодозний зоб. Пацієнтка проходила підготовку до хірургічного лікування впродовж 6 місяців. Перенесла субтотальну тиреоїдектомію. Через 3 місяці після операції вдвох із чоловіком пройшли підготовку до вагітності. Жінка за- вагітніла і виносила дитину. Пологи були без ускладнень.

Аналіз гінекологічної патології за групами обстежуваних показав, що інфекційні процеси піхви в анамнезі мали майже $100 \%$ жінок, запальні процеси шийки матки (ендоцервіцит, цервіцит) - 27 (60,0 \%) і 28 (62,2 \%), лейоміому матки - $13(28,9 \%)$ і $12(26,7 \%)$, ендометріоз - 5 $(11,1 \%)$ і 6 (13,3 \%), хронічний ендометрит - $4(8,9 \%)$ і $5(11,1 \%)$, хронічний сальпінгооофорит - 6 (13,3\%) і 7 $(15,6 \%)$, порушення менструальної функції - 20 (44,4 \%) і 21 (46,7 \%) обстежувана груп Аж і Б. Не виявлено достовірної різниці між результатами обстеження за групами. Майже $100 \%$ жінок впродовж останнього року постійно приймали різноманітні медикаменти.

Висока частота соматичних, гінекологічних, андрологічних захворювань інфекційної етіології підтверджує високий інфекційний індекс у обстежуваного контингенту $-1,8$.

Інфекційні процеси в організмі жінок $є$ визнаними етіологічними чинниками хронічних ендометритів, порушення процесів імплантації. Ендокринопатії, особливо недостатність лютеїнової фрази циклу, є одним із причинних фракторів порушення процесу прогестеронової трансформації ендометрія в децидуальну тканину [1, 2, 9]. Вищенаведене призводить до звичного невиношування вагітності.

Клінічний приклад 2. Пацієнтка 29 років. В анамнезі 1 пологи шляхом кесаревого розтину, рання дитяча смертність. В анамнезі 4 спонтанних аборти у термін 8-9 тижнів впродовж 2 років, дві спроби ЕКЗ без успіху. Виявлено неспроможність тканин матки у ділянці кесаревого розтину. Жінка перенесла дві реконструктивні операції тіла матки. Завагітніла, виносила дитину. Народжувала шляхом кесаревого розтину.

Обстеження чоловіків (група Ач) виявило патологію шлунково-кишкового тракту в 28 (62,2 \%), сечовивідної системи - у 31 (68,9\%), із них хламідійний уретрит - у 17 (54,8 \%), сечостатевий трихомоноз - у 14 (45,2 \%). Патологію сперматогенезу різної етіології виявлено у 14 (31,1 \%) обстежуваних. Патологію урогенітального тракту виявлено у 25 (55,6 \%) чоловіків.

Стан здоров'я майбутнього батька дитини має доведене принципове значення для процесу запліднення, формування та росту зародка, плода $[1,2,4]$. Соматичні захворювання, андрологічна патологія інфекційного генезу в організмі чоловіка сприяють порушенню процесу сперматогенезу, патології ембріона/плода.

Виявлення наявних вищенаведених захворювань організмів жінки і чоловіка розцінюємо як патогенетичне обґрунтування етапу комплексної персоніфікованої передконцепційної підготовки майбутніх батьків до вагітності.

Результати лабораторного визначення алелів генів ферментів фолатного циклу в біологічних рідинах майбутніх батьків на етапі передконцепційної підготовки до вагітності розцінюємо як спадкову схильність до патології мультифракторної природи - звичного невиношування вагітності [25-27]. Наявність поліморфнних (гомо-, гетерозиготних) алелів $є$ патогенетичним обґрунтуванням до персоніфрікованого алгоритму попередження звичного невиношування вагітності, уроджених вад розвитку, репродуктивних втрат у сім'ї тощо [4, 23, 24].

Частоту лабораторного визначення алелів гена ферменту фролатного циклу метилентетрагідрофолатредук- 
тази (MTHFR) в сироватці обстежуваних жінок і чоловіків представлено в таблиці 1.

Результат визначення не мав достовірної різниці між групами жінок і чоловіків, що підтверджує репрезентативність груп.

У жінок груп Аж і Б поліморфізм гомозиготний і гетерозиготний MTHFR був виявлений у 29 (32,2\%) і 39 (43,3 \%) відповідно. Поєднаний поліморфізм мав місце у 34 (75,5 \%) жінок в обох групах. У групі Ач поліморфні гомозиготні алелі виявлено у $14(31,1 \%)$, гетерозиготні - у 21 (46,7 \%). Поєднаний поліморфізм визначено у 35 (77,8 \%) обстежуваних.

Результати проведених досліджень підтверджують важливість визначення алелів генів фрерментів фолатного циклу та застосування фролатів до та під час перебігу вагітності. Адже метаболічною активністю володіє похідне фолієвої кислоти - тетрагідрофролат (THF) (5-MTHF (метилтетрагідрофролат), що міститься в системному кровотоці організму людини). Специфічний фрермент 5,10-метилентетрагідрофолатредуктаза (MTHFR) каталізує відновлення 5,10-метилентетрагідрофолату (MTHF) до 5-MTHF. Саме застосування метафоліну сприяє підвищенню фролатів у плазмі крові незалежно від генотипу мутації 677Ц - Т гена MTHFR [4, 13, 19, 32-34].

Результат визначення кількості поєднаного поліморфрізму алелів генів фрерментів фролатного циклу в обстежуваного контингенту представлено у таблиці 2.

За результатами лабораторного дослідження, поєднаний поліморфізм у обстежуваного контингенту був у межах від 66,7 до 80,0 \% спостережень. Достовірної різниці не було виявлено між показниками у досліджуваних групах. Разом з тим, у групі чоловіків частота зустрічальності поєднаного поліморфізму була вищою, ніж у групах жінок, що підтверджує доцільність обстеження обох біологічних батьків.

Спадкова схильність $€$ фактором ризику виникнення захворювань мультисракторної природи у різному віці людини, в тому числі в ембріональний/сетальний періоди. У «носіїв» поліморфних алелів генів ферментів фолатного циклу порушуються метаболічні процеси фролатного циклу (перетворення амінокислоти гомоцистеїну в амінокислоту метіонін), метаболізм вітамінів та вітаміноподібних сполук групи «В», регуляція окремих біохімічних і фрізіологічних (енергетичний обмін, біосинтез амінокислот, жирних кислот, пуринових та пірамідинових основ тощо) процесів в організмі. Метаболічні порушення в організмі людини $€$ причиною багатьох захворювань мультифакторної природи, в тому числі й звичного невиношування вагітності $[4,22-27]$.

Клінічний перебіг вагітності мав достовірні відмінності ( $<<0,05)$ між групами залежно від алгоритму ведення (запропонованого, стандартного) (табл. 3).

Порівняльний аналіз клінічного перебігу вагітності за триместрами гестації між групами спостереження довів статистично вірогідні відмінності $(p<0,05)$. У групі жінок, які проходили запропоновану персонісіковану комплексну етапну передконцепційну підготовку з батьками дітей, достовірно знижено частоту синдрому загрози раннього викидня у 2,1 раза, відшарування хоріона у 3,6 раза, пізнього викидня у 3,1 раза. Випадків анембріонії, уроджених вад розвитку у плода, передлежання плаценти, відшарування плаценти, передчасних пологів у групі Аж не спостерігали. Отримані результати підтверджують ефективність проведеної підготовки.

Встановлення можливих етіологічних фракторів звичного невиношування вагітності для з'ясовування метаболічних порушень як ланцюгів патогенетичних механізмів $€$ важливим підґрунтям для визначення персоніфрікованого алгоритму попередження гестаційної патології на етапі передконцепційної підготовки.

ВИСНОВКИ. 1. Алгоритм підготовки до вагітності жінок зі звичним невиношуванням в анамнезі має включати обстеження і підготовку майбутніх батьків обох статей (чоловік/жінка).

2. Визначення можливих етіологічних фракторів звичного невиношування вагітності дає можливість розробити персоніфікований алгоритм передконцепційної підготовки організмів майбутніх батьків до природного запліднення.

3. Передконцепційна підготовка до вагітності показана 100 \% жінок і чоловіків за 3-4 місяці до запліднення, і її

Таблиця 1. Частота визначення алелів гена MTHFR у крові обстежуваних, n=135

\begin{tabular}{|c|c|c|c|c|c|c|}
\hline \multirow{3}{*}{$\begin{array}{c}\text { Досліджувані } \\
\text { алелі }\end{array}$} & \multicolumn{6}{|c|}{ Гррупи обстежуваних } \\
\hline & \multicolumn{2}{|c|}{ Аж, $n-45$} & \multicolumn{2}{|c|}{ Ач, $n-45$} & \multicolumn{2}{|c|}{$5, n-45$} \\
\hline & абс. & $\%$ & абс. & $\%$ & абс. & $\%$ \\
\hline T677T & 15 & 33,3 & 14 & 31,1 & 14 & 31,1 \\
\hline C677T & 19 & 42,2 & 21 & 46,7 & 20 & 44,5 \\
\hline C677C & 11 & 24,4 & 10 & 22,2 & 11 & 24,4 \\
\hline
\end{tabular}

Таблиця 2. Характеристика поєднаного поліморфізму алелів генів ферментів фолатного циклу в обстежуваного контингенту, n=135

\begin{tabular}{|c|c|c|c|c|c|c|c|}
\hline \multirow{3}{*}{ Гени } & \multirow{3}{*}{ Поліморфрізм } & \multicolumn{6}{|c|}{ Групи обстежуваних } \\
\hline & & \multicolumn{2}{|c|}{ Аж, $n-45$} & \multicolumn{2}{|c|}{$\mathrm{A} 4, \mathrm{n}-45$} & \multicolumn{2}{|c|}{$5, n-45$} \\
\hline & & абс. & $\%$ & абс. & $\%$ & абс. & $\%$ \\
\hline MTHFR & $1298 \mathrm{~A} / \mathrm{C}$ & 35 & 77,8 & 36 & 80,0 & 34 & 75,6 \\
\hline MTHFR & $677 \mathrm{C} / \mathrm{T}$ & 34 & 75,6 & 35 & 77,8 & 34 & 75,6 \\
\hline MTR & $2756 A>G$ & 31 & 68,9 & 33 & 73,3 & 32 & 71,1 \\
\hline MTRR & $66 A>G$ & 30 & 66,7 & 34 & 75,6 & 33 & 73,3 \\
\hline
\end{tabular}


Таблиця 3. Клінічний перебіг вагітності в обстежуваних жінок, n=90

\begin{tabular}{|c|c|c|c|c|}
\hline \multirow{3}{*}{ Ускладнення перебігу вагітності } & \multicolumn{4}{|c|}{ Групи обстежуваних, n=90 } \\
\hline & \multicolumn{2}{|c|}{ Аж, $n=45$} & \multicolumn{2}{|c|}{ E, $n=45$} \\
\hline & абс. & $\%$ & абс. & $\%$ \\
\hline \multicolumn{5}{|l|}{ Перший триместр } \\
\hline Синдром загрози раннього викидня & 8 & 17,8 & 17 & $37,8^{*}$ \\
\hline Спонтанний аборт & - & - & 7 & $15,6^{*}$ \\
\hline Відшарування хоріона & 3 & 6,7 & 11 & $24,4^{*}$ \\
\hline Аборт, що не відбувся & - & - & 4 & $10,5^{*}$ (із 38) \\
\hline Анембріонія & - & - & 3 & $6,7^{*}$ \\
\hline Ранній токсикоз & 5 & 11,1 & 14 & $31,1^{*}$ \\
\hline Уроджені вади розвитку & - & - & 2 & $4,4^{\star}$ \\
\hline Передлежання хоріона & 2 & 4,4 & 5 & 11,1 \\
\hline Анемія вагітних & - & - & 13 & $28,9 *$ \\
\hline \multicolumn{5}{|l|}{ Другий триместр } \\
\hline & \multicolumn{4}{|c|}{ Групи обстежуваних, n=89 } \\
\hline & \multicolumn{2}{|c|}{ Аж, $n=45$} & \multicolumn{2}{|c|}{$5, n=34$} \\
\hline & абс. & $\%$ & абс. & $\%$ \\
\hline Плацентарна диссрункція & 7 & 15,6 & 16 & $47,1^{*}$ \\
\hline Синдром загрози пізнього викидня & 3 & 6,7 & 7 & $20,6^{*}$ \\
\hline Антенатальна загибель плода & - & - & 1 & $2,9^{*}$ \\
\hline Уроджені вади розвитку у плода & - & - & 1 & $2,9^{*}$ \\
\hline Низька плацентація & 2 & 4,4 & 5 & 11,1 \\
\hline Передлежання плаценти & - & - & 1 & $2,9^{\star}$ \\
\hline Анемія & 3 & 6,7 & 13 & $38,2^{*}$ \\
\hline \multicolumn{5}{|l|}{ Третій триместр } \\
\hline & \multicolumn{4}{|c|}{ Групи обстежуваних, n=89 } \\
\hline & \multicolumn{2}{|c|}{ Аж, $n=45$} & \multicolumn{2}{|c|}{$5, n=34$} \\
\hline & абс. & $\%$ & абс. & $\%$ \\
\hline Плацентарна диссрункція & 7 & 15,6 & 16 & $47,1^{*}$ \\
\hline Передчасне відшарування часткове плаценти & - & - & 9 & $26,5^{\star}$ \\
\hline Передчасні пологи & - & - & 2 & $5,9^{*}$ \\
\hline Низька плацентація & - & - & 5 & $11,1^{*}$ \\
\hline Передлежання плаценти & - & - & 1 & $2,9^{*}$ \\
\hline Прееклампсія & - & - & 4 & $11,8^{\star}$ \\
\hline Анемія & - & - & 18 & $52,9^{*}$ \\
\hline
\end{tabular}

Примітка. * - статистично вірогідний результат щодо групи жінок Аж, p<0,05.

алгоритм має бути персоніфікованим, етапним, комплексним, патогенетично обґрунтованим, в тому числі за результатами спадкової схильності до порушень фолатного циклу шляхом визначення алелів генів фрерментів фролатного циклу в біологічному матеріалі організмів жінок та чоловіків.

\section{СПИСОК ЛІТЕРАТУРИ}

1. Вартанян Э. А. Анализ современных подходов к оценке эфрфективности медицинской помощи пациенткам с привычным невынашиванием беременности / Э. А. Вартанян, О. В. Гриднев, А. В. Белостоцкий // Проблемы социальной гигиены, здравоохранения и истории медицины. - 2018. - № 4. - С. 236 -239.

2. Антипкин Ю. Г. Основные направления развития перинатальной медицины / Ю. Г. Антипкин, Ю. В. Давыдова // Репродуктивная эндокринология. - 2012. - № 2 (4). - С. 5-7.
4. «Носіям» поліморфнних алелів генів фрерментів фолатного циклу рекомендовано фролатвмісні препарати («Метафолін») у фрізіологічних дозах.

ПЕРСПЕКТИВИ ПОДАЛЬШИХ ДОСЛІДЖЕНЬ. Перспективи подальших досліджень полягають у вдосконаленні діагностики гестаційних ендотеліозів.

3. Изменения обмена коллагена в ткани внутриматочной перегородки у женщин, страдающих привычным невынашиванием / В. Н. Запорожан, И. 3. Гладчук, В. Г. Маричереда, Н. Н. Рожковская // Репродуктивна ендокринологія. - 2016. - № 4 (30). - С. 32- 35.

4. Руденко І. В. Патогенетичне обгрунтування персоніфрікованої корекції порушень фолатного циклу за допомогою комплексу з метафроліном для профрілактики вроджених вад розвитку / І. В. Руденко, В. П. Міщенко // 
Репродуктивна ендокринологія. - 2020. - № 2 (52). C. $67-72$.

5. Досова С. Ю. Исследование маркеров повреждения головного мозга и цитокинов у пациенток с привычным невынашиванием беременности / С. Ю. Досова, И. И. Стольникова, Н.Н.Слюсарь // Российский вестник акушера-гинеколога. - 2019. - № 5. - С. 13-17.

6. Изменения гемостаза по данным тестов тромбодинамики и контракции сгустков крови у женщин с привычным невынашиванием беременности в анамнезе / А. Д. Пешкова, С. И. Сафиуллина, Д. Г. Асарова [и др.] // Акушерство и гинекология. - 2019. - № 12. - С. 111-119.

7. Особенности заболеваний шейки матки у беременных с привычным невынашиванием в анамнезе / С. В. Ушакова, Н. В. Зароченцева, Н. С. Меньшикова, Л. В. Кешьян // Российский вестник акушера-гинеколога. - 2017. - № 2. - С. 13-19.

8. Роль CD178+ мононуклеарных клеток в развитии угрожающего позднего выкидыша у женщин с угрозой прерывания беременности в I триместре и привычным невынашиванием в анамнезе / Н. В. Батрак, А. И. Малышкина, Н. Ю. Сотникова, Н. В. Крошкина // Акушерство и гинекология. - 2020. - № 5. - С. 70-77.

9. Состояние биоценоза у беременных женщин с привычным невынашиванием в анамнезе / А. В. Соловьева, О. П. Герасимова, К. С. Ермоленко [и др.] // Акушерство и гинекология. - 2018. - № 10. - С. 106-111.

10. Cervical length and obstetric history predict spontaneous preterm birth: development and validation of a model to provide individualized risk assessment / E. Celik, M. To, K. Gajewska [et al.] // Ultrasound Obstet. Gynecol. - 2011. - Vol. 31 (5). P. 549-554.

11. Pregnancy-related mortality in the United States 20062010 / A. A. Creanga, C. J. Berg, C. Syverson [et al.] // Obstet. Gynecol. - 2015. - Vol. 125 (1). - P. 5-12.

12. Devall A. J. Sporadic pregnancy loss and recurrent miscarriage / A. J. Devall, A. Coomarasamy // Best Pract. Res. Clin. Obstet. Gynaecol. - 2020. - Vol. 69. - P. 30-39.

13. Folate deficiency and folic acid supplementation: the prevention of neural-tube defects and congenital heart defects / A. E. Czeizel, I. Dudas, A. Vereczkey, F. Bánhidy // Nutrients. 2013. - Vol. 5 (11). - P. 4760-4775.

14. A case-control study of placental lesions associated with preeclampsia / L. Devisme, B. Merlot, A. Ego [et al.] // Int. J. Gynaecol. Obstet. - 2013. - Vol. 120 (2). - P. 165-168.

15. Dodd J. M. The role of progesterone in prevention of preterm birth / J. M. Dodd, C. A. Crowther // Int. J. Womens Health. - 2009. - Vol 1. - P. 73-84.

16. Foetal and maternal outcomes in hyperuricaemia pre-eclampsia patients in Hospital Universiti Sains Malaysia/ F. Jummaat, A. S. Adnan, S. A. Ab Hamid [et al.] // J. Obstet. Gynaecol. - 2021. - Vol. 41 (1). - P. 38-43.

17. Figueras F. Intrauterine growth restriction: new concepts in antenatal surveillance, diagnosis, and management / F. Figueras, J. Gardosi // Am. J. Obstet. Gynecol. - 2011. Vol. 204 (4). - P. 288-300.

18. Hasan Ç. Investigation of copeptin levels in foetal congenital central nervous system anomalies / Ç. Hasan // J. Obstet. Gynaecol. - 2021. - Vol. 41 (1). - P. 49-54.

19. Homer H. A. Modern management of recurrent miscarriage / H. A. Homer // Aust. N. Z. J. Obstet. Gynaecol. - 2019. - Vol. 59 (1). - P. 36-44. DOI: 10.1111/ajo.12920.

20. Hypertensive disorders and pregnancy-related stroke: frequency, trends, risk factors, and outcomes / L. R. Leffert, C. R. Clancy, B. T. Bateman [et al.] // Obstet. Gynecol. - 2015. - Vol. 125 (1). - P. 124-131.
21. Menon R. Preterm birth: a global burden on maternal and child health / R. Menon // Pathog. Glob. Health. - 2012. Vol. 106 (3). - P. 139-140.

22. Баранов В. С. Генетический паспорт - основа индивидуальной и предиктивной медицины / В. С. Баранов. - СПб. Изд-во Н-Л, 2009. - 528 с.

23. Венцковский Б. М. Полиморфизм генов фолатного обмена как причина преждевременных родов / Б. М. Венцковский, А. С. Загородняя, С. Ст. Леуш // Репродуктивное здоровье. Восточная Европа. - 2015. - № 4. - С. 8-15.

24. Гриневич Т. Н. Частота встречаемости и ассоциация с ранними эмбриональными потерями полиморфизмов G1691A гена фрактора V (LEIDEN), 675 4G/5G гена PAI-I, 455G/А гена FGB, 735 C/T гена MMP-2 и 418 C/G гена TIMP-2 у женщин с привычным невынашиванием беременности / Т.Н.Гриневич, С.А.Ляликов, Т. Л. Степуро // Репродуктивное здоровье. Восточная Европа. - 2019. - № 5. - С. 577-585.

25. Роль полиморфизма генов системы гемостаза и фрерментов фолатного цикла в формировании ретрохориальной гематомы / Н. Б. Кузнецова, И. О. Буштырева, А. Е. Донников [и др.] // Акушерство и гинекология. - 2017. - № 3. - С. 62-66.

26. Эффрективность преимплантационного генетического скрининга у пациенток с привычным невынашиванием беременности и бесплодием / О. Е. Коротченко, А. Г. Сыркашева, Н.В.Долгушина [и др.] // Акушерство и гинекология. - 2018. - № 3. - C. 64-69.

27. Engel S. M. Polymorphisms in folate metabolizing genes and risk for spontaneous preterm and small for gestational age birth / S. M. Engel, A. R. Olshan, A. M. Siega-Riz // Am. J. Obstet. Gynecol. - 2006. - Vol. 195 (5). - P. 1231.e1-11.

28. Vaginal progesterone in women with an asymptomatic sonographic short cervix in the midtrimester decreases preterm delivery and neonatal mobility; a systematic review and metaanalysis of individual patient data / R. Romero, K. Nicolaides, A. Conde-Agutelo [et al.] // Am. J. Obstet. Gynecol. - 2012. Vol. 206 (2). - P. 124.e1-19.

29. Factors contributing to favourable neonatal outcomes in early- onset severe preeclampsia / Y. Sato, K. Moriuchi, C. Sakae-Matsumoto [et al.] // J. Obstet. Gynaecol. - 2021. Vol. 41 (1). - P. 60-65.

30. Комплексная терапия вагинальных вируснобактериальных инфекций у женщин с привычным невынашиванием / А. В. Соловьева, О. П. Герасимова, К. С. Ермоленко, Д. А. Геворгян // Акушерство и гинекология. - 2018. - № 11. - С. 122-126.

31. Опыт применения сулодексида для улучшения внутриматочной гемодинамики у пациенток с первичным привычным невынашиванием беременности / А. Г. Ящук, А. В. Масленников, И. Б. Фаткуллина [и др.] // Акушерство и гинекология. - 2019. - № 10. - С. 172-178.

32. Use of complementary and alternative medicines during the third trimester / A. R. Pallivalapila, D. Stewart, A. Shetty [et al.] // Obstet. Gynecol. - 2015. - Vol. 125 (1). - P. 204-211.

33. Supplementation with progestogens in the first trimester of pregnancy to prevent miscarriagein women with unexplained recurrent miscarriage: a systematic review and meta-analysis of randomized, controlled trials / G. Saccone, C. Schoen, J. M. Franasiak [et al.] // Fertil. Steril. - 2017. - Vol. 107 (2). P. 430-438.e3. DOI: 10.1016/j.fertnstert.2016.10.031.

34. Maternal supplementation with folic acid and other vitamins and risk of leukemia in offspring / C. Metayer, E. Milne, I. D. Dockerty [et al.] // Epidemiology. - 2014. - Vol. 25 (6). - P. 811-822.

35. Modeling fetal-maternal heart-rate interaction / P. Van Leeuwen, D. Geue, S. Lange, D. H. Grönemeyer // IEEE Eng. Med. Biol. Mag. - 2009. - Vol. 28 (6). - P. 49-53. 


\section{REFERENCES}

1. Vartanyan, E.A, Gridnev, O.V., \& Belostotskiy, A.V., Pesennikova, Ye.V., Gadaboshev, M.I., \& Kuchits, S.S. (2018). Analiz sovremennykh podkhodov $k$ otsenke effektivnost meditsinskoy pomoshchi patsiyentkam s privychnym nevynashivaniyem beremennosti, [Analysis of modern approaches to assessing the effectiveness of medical care for patients with recurrent miscarriage]. Problemy sotsialnoy gigiyeny, zdravookhraneniya i istorii meditsiny - Problems of Social Gygiene, Health Care and History of Medicine, 4, 236239 [in Russian]

2. Antipkin, Yu.G., \& Davydova, Yu.G. (2012). Osnovnye napravleniya razvitiya perinatalnoy meditsiny [The main directions of development of perinatal medicine]. Reproduktivnaya endokrinologiya - Reproductive Endocrinology, 2 (4), 5-7 [in Ukrainian].

3. Zaporozhan, V.N., Gladchuk, V.I., Marichereda, V.G., \& Rozhkovskaya, N.N. (2016). Izmeneniya obmena kollagena $v$ tkani vnutrimatochnoy peregorodki u zhenshchin, stradayushchikh privychnym nevynashivaniyem [Changes in collagen metabolism in the tissue of the intrauterine septum in women suffering from recurrent miscarriage]. Reproduktivnaya endokrinologiya - Reproductive Endocrinology, 4 (30), 32-35 [in Ukrainian].

4. Rudenko, I.V., \& Mishchenko, V.P. (2020). Patohenetychne obrhuntuvannia personifikovanoi korektsii porushen folatnoho tsyklu za dopomohoiu kompleksu z metafolinom dlia profilaktyky vrodzhenykh vad rozvytku [Pathogenetic substantiation of personalized correction of folate cycle disorders using a complex with metafolin for the prevention of congenital malformations]. Reproduktivnaya endokrinologiya - Reproductive Endocrinology, 2 (52), 67-72 [in Ukrainian]

5. Dosova, S.Yu., Stolnikova, I.I., \& Slyusar, N.N. (2019). Issledovaniye markerov povrezhdeniya golovnogo mozga i tsitokinov u patsiyentok s privychnym nevynashivaniyem beremennosti [Study of markers of brain damage and cytokines in patients with recurrent miscarriage]. Rossiyskiy vestnik akushera-ginekologa - Russian Bulletin of ObstetricianGynecologist, 5, 13-17 [in Russian].

6. Peshkova, A.D., Safiullina, S.I.,Asarova, D.G., Khafizova,A.F., Ataullakhanov, F.I., \& Litvinov, R.I. (2019). Izmeneniya gemostaza po dannym testov trombodinamiki i kontraktsii sgustkov krovi u zhenshchin s privychnym nevynashivaniyem beremennosti v anamneze [Changes in hemostasis according to thrombodynamic tests and blood clot contraction in women with a history of recurrent miscarriage]. Akusherstvo i ginekologiya Obstetrics and Gynecology, 12, 111-119 [in Russian].

7. Ushakova, S.V., Zarochentseva, N.V., Menshikova, N.S., \& Keshyan, L.V. (2017). Osobennosti zabolevaniy sheyki matk $\mathrm{u}$ beremennykh s privychnym nevynashivaniyem $v$ anamneze [Features of cervical diseases in pregnant women with a history of recurrent miscarriage]. Rossiyskiy vestnik akusheraginekologa - Russian Bulletin of Obstetrician-Gynecologist, 2, 13-19 [in Russian].

8. Batrak, N.B., Malyshkina, A.I., Sotnikova, N.Yu., \& Kroshkina, N.V. (2020). Rol CD178+ mononuklearnykh kletok $v$ razvitii ugrozhayushchego pozdnego vykidysha $u$ zhenshchin s ugrozoy preryvaniya beremennosti v I trimestre i privychnym nevynashivaniyem $v$ anamneze [The role of CD178 + mononuclear cells in the development of threatening late miscarriage in women with the threat of termination of pregnancy in the first trimester and recurrent miscarriage in history]. Akusherstvo i ginekologiya - Obstetrics and Gynecology, 5, 70-77 [in Russian].

9. Solovyeva, A.V., Gerasimova, O.P., Yermolenko, K.S., \& Gevorgyan, D.A. (2018). Sostoyaniye biotsenoza u beremennykh zhenshchin s privychnym nevynashivaniyem $v$ anamneze, [The state of biocenosis in pregnant women with a history of recurrent miscarriage]. Akusherstvo i ginekologiya Obstetrics and Gynecology, 10, 106-111 [in Russian].

10. Celik, E., To, M., Gajewska, K., Smith, G.C., \&Nicolaides, K.H. (2011). Cervical length and obstetric history predict spontaneous preterm birth: development and validation of a model to provide individualized risk assessment. Ultrasound Obstet. Gynecol., 31 (5), 549-554. DOI: 10.1002/uog.5333.

11. Creanga,A.A., Berg, C.J., Syverson, C., Seed, K., Bruce, F.C., \& Callaghan, W.M. (2015). Pregnancy-related mortality in the United States 2006-2010. Obstetrics and Gynecology, 125 (1), 5-12. DOI: 10.1097/AOG.0000000000000564.

12. Devall, A.J., \& Coomarasamy, A. (2020). Sporadic pregnancy loss and recurrent miscarriage. Best Prac. Res. Clin. Obstet. Gynaecol., 69, 30-39. DOI: 10.1016/j.bpobgyn.2020.09.002.

13. Czeizel, A.E., Dudas, I., Vereczkey, A., \& Bánhidy, F. (2013). Folate deficiency and folic acid supplementation: the prevention of neural-tube defects and congenital heart defects. Nutrients, 5 (11), 4760-4775. DOI: 10.3390/nu5114760.

14. Devisme, L., Merlot, B., Ego, A., Houfflin-Debarge, V., Deruelle, P., \& Subtil, D. (2013). A case-control study of placental lesions associated with preeclampsia. Int. J. Gynaecol. Obstet., 120 (2), 165-168. DOI: 10.1016/j.ijgo.2012.08.023.

15. Dodd, J.M. \& Crowther, C.A. (2009). The role o progesterone in prevention of preterm birth. Int. J. Women's Health, 1, 73-84. DOI: 10.2147/ijwh.s4730.

16. Jummaat, F., Adnan, A.S., Ab Hamid, S.A., Hor, J.N., Nik Mustofar, N.N., Muhammad Asri, N.A., ..., \& Che Hasnan, N.A. (2021). Foetal and maternal outcomes in hyperuricaemia pre-eclampsia patients in Hospital Universiti Sains Malaysia. J. Obstet. Gynaecol., 41 (1), 38-43. DOI: 10.1080/01443615.2019.1679731.

17. Figueras, F., \& Gardosi, J. (2011) Intrauterine growth restriction: new concepts in antenatal surveillance, diagnosis, and management. Am. J. Obstet. Gynecol., 204 (4), 288-300. DOI: 10.1016/j.ajog.2010.08.055.

18. Hasan, Ç. (2021). Investigation of copeptin levels in foetal congenital central nervous system anomalies. J. Obstet. Gynaecol., 41 (1), 49-54. DOI: 10.1080/01443615.2019.1705774.

19. Homer, H.A. (2019). Modern management of recurrent miscarriage. Aust. N. Z. J. Obstet. Gynaecol., 59 (1), 36-44. DOI: 10.1111/ajo.12920.

20. Leffert, L.R., Clancy, C.R., Bateman, B.T., Bryant, A.S., \& Kuklina, E.V. (2015). Hypertensive disorders and pregnancy-related stroke: frequency, trends, risk factors, and outcomes. Obstet. Gynecol., 125 (1), 124-131. DOI: 10.1097/ AOG.0000000000000590

21. Menon, R. (2012). Preterm birth: a global burden on maternal and child health. Pathog. Glob. Health, 106 (3),139140. DOI: $10.1179 / 204777312 \times 13462106637729$.

22. Baranov, V.S. (2009). Geneticheskiy pasport - osnova individualnoy i prediktivnoy meditsiny [Genetic passport - the basis of individual and predictive medicine]. Saint-Petersburg: Izd-vo N-L [in Russian].

23. Ventskovskiy, B.M., Zagorodnyaya, A.S., \& Leush, S.St. (2015). Polimorfizm genov folatnogo obmena kak prichina prezhdevremennykh rodov [Polymorphism of folate metabolism genes as a cause of preterm labor]. Reproduktivnoye zdorovye. Vostochnaya Yevropa - Reprod. Health. East. Eur., 4, 8-15 [in Ukrainian].

24. Grinevich, T.N., Lyalikov, S.A., \& Stepuro, T.L. (2019). Chastota vstrechayemosti i assotsiatsiya $s$ rannim i embrionalnymi poteryami polimorfizmov G1691A gena faktora V (LEIDEN), 675 4G/5G gena PAI- I, 455G/A gena FGB, 735 
C/T gena MMP-2 i 418 C/G gena TIMP-2 u zhenshchin s privychnym nevynashivaniyem beremennosti, [Frequency of occurrence and association with early and embryonic losses of polymorphisms G1691A of the factor $V$ gene (LEIDEN), 675 $4 \mathrm{G} / 5 \mathrm{G}$ of the PAI-I gene, $455 \mathrm{G} / \mathrm{A}$ of the FGB gene, $735 \mathrm{C} / \mathrm{T}$ of the MMP-2 gene, and $418 \mathrm{C} / \mathrm{G}$ of the TIMP-2 gene in women with recurrent miscarriage]. Reproduktivnoye zdorovye. Vostochnaya Yevropa-Reprod. Health. East. Eur., 5, 577-585 [in Ukrainian].

25. Kuznetsova, N.B., Bushtyreva, I.O., \& Donnikov, A.Ye., Mashkina, Ye.V., \& Dybova, V.S. (2017). Rol polimorfizma genov sistemy gemostaza i fermentov folatnogo tsikla $v$ formirovanii retrokhorialnoy gematomy [The role of polymorphism of genes of the hemostasis system and enzymes of the folate cycle in the formation of retrochorial hematoma]. Akusherstvo i ginekologiya - Obstetrics and Gynecology, 3, 62-66 [in Russian].

26. Korotchenko, O.Ye., Syrkasheva, A.G., Dolgushina, N.V., Kulakova, Ye.V., Dokshukina, A.A., \& Yekimov, A.N. (2018). Effektivnost preimplantatsionnogo geneticheskogo skrininga u patsiyentok s privychnym nevynashivaniyem beremennosti i besplodiyem [Efficiency of preimplantation genetic screening in patients with recurrent miscarriage and infertility]. Akusherstvo i ginekologiya - Obstetrics and Gynecology, 3, 64-69 [in Russian].

27. Engel, S.M., Olshan, A.F., Siega-Riz, A.M., Savitz, D.A., \& Chanock, S.J. (2006). Polymorphisms in folate metabolizing genes and risk for spontaneous preterm and small for gestational age birth. Am. J. Obstet.Gynecol., 195 (5), 1231. DOI: 10.1016/j. ajog.2006.07.024.

28. Romero, R., Nicolaides, K., Conde-Agudelo, A., Tabor, A., O'Brien, J.M., Cetingoz, E., ..., \& Hassan, S.S. (2012). Vaginal progesterone in women with an asymptomatic sonographic short cervix in the midtrimester decreases preterm delivery and neonatal mobility; a systematic review and metaanalysis of individual patient data. Obstet. Gynecol., 206 (2), 124.e1-19. DOI: 10.1016/j.ajog.2011.12.003.

29. Sato, Y., Moriuchi, K., Sakae-Matsumoto, C., Ueda, M., \& Fujita, K. (2021). Factors contributing to favourable neonatal outcomes in early-onset severe preeclampsia. J. Obstet. Gynaecol., 41 (1), 60-65. DOI: 10.1080/01443615.2019.1706160.

30. Solovyeva, A.V., Gerasimova, O.P., Yermolenko, K.S., \& Gevorgyan, D.A. (2018). Kompleksnaya terapiya vaginalnykh virusno-bakterialnykh infektsiy u zhenshchin s privychnym nevynashivaniyem [Complex therapy of vaginal viral and bacterial infections in women with recurrent miscarriage]. Akusherstvo i ginekologiya - Obstetrics and Gynecology, 11, 122-126 [in Russian].

31. Yashchuk, A.G., Maslennikov, A.V., Fatkullina, I.B., Rakhmatullina, I.R., Berg, E.A., \& Berg, P.A. (2019). Opyt primeneniya sulodeksida dlya uluchsheniya vnutrimatochnoy gemodinamiki u patsiyentok $s$ pervichnym privychnym nevynashivaniyem beremennosti [Experience of using sulodexide to improve intrauterine hemodynamics in patients with primary recurrent miscarriage]. Akusherstvo i ginekologiya - Obstetrics and Gynecology, 10, 172-178 [in Russian].

32. Pallivalapila, A.R., Stewart, D., Shetty, A., Pande, B., Singh, R., \& McLay, J.S. (2015). Use of complementary and alternative medicines during the third trimester. Obstet. Gynecol., 125 (1), 204-211. DOI: 10.1097/AOG.0000000000000596.

33. Saccone, G., Schoen, C., Franasiak, J.M., Scott, R.T. Jr, \& Berghella, V. (2017). Supplementation with progestogens in the first trimester of pregnancy to prevent miscarriagein women with unexplainedre current miscarriage: a systematic review and meta-analysis of randomized, controlled trials. Fertil. Steril., 107 (2), 430-438.e3. DOI: 10.1016/j.fertnstert.2016.10.031.

34. Metayer, C., Milne, E., Dockerty, J.D., Clavel, J., Pombode-Oliveira, M.S., Wesseling, C., ..., \& Infante-Rivard, C. (2014). Maternal supplementation with folic acid and other vitamins and risk of leukemia in offspring. Epidemiology, 25 (6), 811-822. DOI: 10.1097/EDE.0000000000000141.

35. Van Leeuwen, P., Geue, D., Lange, S., \& Grönemeyer, D.H. (2009). Modeling fetal-maternal heart-rate interaction. IEEE Eng. Med. Biol. Mag., 28 (6), 49-53. DOI: 10.1109/ MEMB.2009.934625.

Отримано 22.03.21

Прийнято до друку 23.04.21

Електронна адреса для листування: mischenko_vasil@i.ua 